\title{
Agro morphological Characterization and Evaluation of Okra [Abelmoschus esculentus (L.) Moench] Genotypes for Yield and Other Variability Components at Melkassa, Central Ethiopia
}

\begin{abstract}
Okra [Abelmoschus esculentus (L).Moench] is one of indigenous and endemic genetic resource of Ethiopia as well as Benishangul Gumuz, but only few studies were carried out to assess its diversity and performance throughout the country and specifically no research conducted to assess diversity of okra within regional state. Therefore, this study was conducted with the objective of assess the genetic divergence and estimate the genetic variability components in okra genotypes collected from regional state. A total of 36 genotypes were evaluated of which 33okra genotypes were collected from different areas of Benishangul Gumuz Regional State, 3(three) checks, of 2 introduced and 1(one) released were evaluated for 27 quantitative traits at MARC in year 2018/19 using simple lattice design $(6 \times 6)$. The results from analysis of variance revealed that the presence of significant variation for all quantitative traits except 3 traits. Moreover, the variation of genotypes for fruit yield per hectare ranged from 9.44 to $32.88 \mathrm{ton} / \mathrm{ha}^{-1}$ with mean $19.59 \mathrm{ton} /$ ha $^{-1}$ for genotypes 29620 and 29618, respectively. Most of genotypes had high mean performance as compared to checks for majority of traits. The genotypic (GCV) and phenotypic (PCV) coefficient of variation showed within range of 6.3 to $54.19 \%$ and 9.19 to $55.51 \%$, respectively. Heritability in broad sense $\left(\mathrm{H}^{2}\right)$ and genetic advance as percent of mean (GAM) had ranged from 43.46 to $97.34 \%$ and 9.16 to $109.14 \%$, respectively. The variability components (GCV, $\mathrm{PCV}, \mathrm{H}^{2}$ and $\mathrm{GAM}$ ) were high for all traits except few traits like days to $90 \%$ maturity, hundred seed weight low in PCV and GCV. Number of ridge and hundred seed weight showed moderate $\mathrm{H}^{2}$ whereas days to $90 \%$ maturity, number of ridge and percentage of mucilage content had moderate GAM and low for hundred seed weight. The result observed in this study was the presence of a wide genetic variation among genotypes collected from Benishangul Gumuz Regional State.
\end{abstract}

Keywords: diversity, genotype, phenotype, quantitative traits, variability components
Volume 5 Issue 2 - 2020

\author{
Nesru Temam,' Wassu Mohamed,'2 Shimelis \\ Aklilu $^{3}$ \\ 'Ethiopian Biodiversity Institute, Ethiopia \\ ${ }^{2}$ School of Plant Sciences, Haramaya University, Ethiopia \\ ${ }^{3}$ Ethiopian Institute of Agricultural Research, Ethiopia
}

\begin{abstract}
Correspondence: Nesru Temam, Msc, Crop and horticulture Directorate, Ethiopian Biodiversity Institute P.O. Box: 30726 . Addis Ababa Ethiopia, Tel +251911995366, Email nesrutemam25@gmail.com
\end{abstract}

Received: March II, 2020 | Published: April 21, 2020

\section{Introduction}

Okra [Abelmoschus esculentus (L.) Moench] belongs to family Malvaceae and it is very important vegetable crop grown in tropical and sub-tropical parts of the world. ${ }^{1}$ Okra is originated in Tropical Africa and it is native to North Eastern Africa in the area of Ethiopia and Sudan from where it extensively spread to Asia, America, Southern Europe and other countries. ${ }^{2}$ It is self-pollinated, mainly propagated by seeds with a duration of 3 to 4 months.,

Cultivated okra constitutes a major economic crop in Asia, West and Central Africa and in America as a result of its vital importance as a component of various recipes in many cuisines and industrial preparations. It hascontribution tohuman diet and medicine by supplying fats, proteins, carbohydrates, minerals, and vitamins..$^{5-7}$ The seed is used as a coffee additive or substitute. ${ }^{8}$

Although okra is traditionally cultivated over years from landraces and low exchange of genotypes among farmers of southwestern and western parts of Ethiopia ${ }^{9-11}$ and till there is no complete data on production area and productivity of okra in Ethiopia. However, recently in 2016 the first improved variety (Bamia Humera) has been recommended for cultivation. ${ }^{12}$ In Ethiopia, little attention has been given to okra research, conservation, and development and it was recommended the need for immediate action to conserve okra germplasm..$^{13}$ In this regard, morphological characterization of plants has been recommended as the first step to be adopted prior to farreaching molecular research and biochemical analyses. ${ }^{14}$

The recently conducted research tried to characterize and reported the presence of diversity in okra collection in Ethiopia. ${ }^{9-11,15-17}$ However, these studies did not focus to assess the genetic variability among okra genotypes in each major okra growing region in Ethiopia. In such situation, it is expected that the crop population in different regions is diverse with each other. This is because genetic differentiation and thereby the presence of population structure is the function geographic distances and environment differences are the two major causes of genetic diversity among plant populations.

Benishangul Gumuz Regional State is one of the potential producers of okra among the major producers and many genotypes collected from regional state but no one can try to investigate the genetic variability as well as their yield performance and related traits. Therefore, this research focusing on the assessment of diversity among okra genotypes collected from Benishangul Gumuz Regional Stateis important to generate additional information and fill the gap of 
insufficient information generated on okra germplasm in the region. The information generated from such study also helps to design appropriate okra breeding and germplasm conservation strategiesin the region. Therefore, this research is intended to attain with the objectives to assess the agro morphological performance and estimate the genetic variability components in okra genotypes collected from Benishangul Gumuz Regional State.

\section{Materials and methods}

\section{Description of study area}

The study was conducted at Melkassa Agriculture Research center (MARC), Ethiopia in 2018/19 main cropping season. Malkasa is located $8^{\circ} 24^{\prime} \mathrm{N}$ latitude and $39^{\circ} 21^{\prime} \mathrm{E}$ by having a distance of around 112 K.M from Addis Abeba on the Eastern direction at an altitude of $1550 \mathrm{~m}$.a.s.l. The area is characterized by low and erratic rainfall with a mean annual rainfall of $763 \mathrm{~mm}$ with peaks in July and August. The dominant soil type of the center is andosol of volcanic origin with $\mathrm{pH}$ that ranges from 7 to 8.2 . The mean annual temperature is $21.2^{\circ} \mathrm{C}$ with a minimum of $14^{\circ} \mathrm{C}$ and a maximum of $28.4^{\circ} \mathrm{C} .^{18}$

\section{Experimental materials and design}

A total of 36 genotypes were evaluated of which 33 okra genotypes were collected from different areas of Benishangul Gumuz Regional State of Ethiopian by Ethiopian Biodiversity Institute and 2 (two) of the varieties were introduced from India and now registered as commercial variety in Ethiopia by one company and 1 (one) variety is released from Humera research center. The okra genotypes were collected at different altitudes ranging from 661 to 1518 m.a.s.1. The three registered varieties will be used as the standard checks. Genotypes were evaluated on the field in $6 \times 6$ simple lattice designs. Each plot had $0.8 \mathrm{~m} \times 5.4 \mathrm{~m}\left(4.32 \mathrm{~m}^{2}\right)$ consisting of one row and a total of 12 plants per row or per plot. The spacing between plant, plots and adjacent replications were $0.45,0.8$ and $2 \mathrm{~m}$, respectively. Three seeds were sown and thinned to one plant per hill when plants reached 4-5 leaves stage.

\section{Data collections}

International Plant Genetic Resources Institute ${ }^{19}$ descriptor list for okra species were used to record data on quantitative and qualitative traits. Quantitative traits were recorded from 10 plants per row leaving the two plants grown at both ends of the row as border plants and the two border plants were used for mature pod and seed traits measurement. Five randomly selected tender fruits from each harvest in each plot were used to record tender fruit characters.

Crop phenology and growth traits: Days to emergence (50\%), days to first flowering, days to $50 \%$ flowering, days to $90 \%$ maturity, number (frequency) of harvest, plant height $(\mathrm{cm})$, stem diameter $(\mathrm{cm})$, number of primary branches, number of internode, internodes length $(\mathrm{cm})$, leaf length $(\mathrm{cm})$, leaf width $(\mathrm{cm})$, number of epicalyxes, and peduncle length $(\mathrm{cm})$ was measured properly.

Pod yield and yield component: Fruit length $(\mathrm{cm})$, fruit diameter $(\mathrm{mm})$, average fruit weight $(\mathrm{g})$, number of tender fruit per plant, fruit yield per plant $(\mathrm{kg})$, fruit yield per hectare $\left(\mathrm{t} / \mathrm{ha}^{-1}\right)$, number of seed per fruit, hundred seed weight $(\mathrm{g})$, seed yield per plant $(\mathrm{g})$, and seed yield per hectare $(\mathrm{kg})$ was taken accordingly.

Tender fruit quality related traits: Dry matter content of tender fruit $(\%)$ and estimation of mucilage content of fruit (\%) were also employed at laboratory.

\section{Data analysis}

Analysis of variance and descriptive statistics: The quantitative data were subjected to analysis of variance (ANOVA) and computed with SAS statistical software $(9.0){ }^{20}$ The quantitative data were collected in simple lattice (partially balanced or incomplete block) design and analysis of variance was computed considering the general linear model as follows.

$$
Y i j k=\mu+r i+G j+b(r) i k+e i j k
$$

The mean performance of genotypes comparison was done following the significance of mean squares using Duncans Multiple Range (DMRT) at $\mathrm{P}<0.05$. The traits that exhibited significant mean squares in general ANOVA were further subjected to genetic analyses.

Analysis of variability components: Based on mean square expectations from the analysis of variance, phenotypic and genotypic coefficients of variations was calculated as suggested by Burton and De vane ${ }^{21}$ and Sivasubramaniah and Menon, ${ }^{22}$ respectively and categorized as low, moderate and high.

\section{Heritability and genetic advances}

Broad-sense heritability values were estimated using the formula adopted by Falconer and Mackay ${ }^{23}$ and the percentage was categorized as low, moderate and high as suggested by Robinson et al. ${ }^{24}$ Whereas, genetic advance in the absolute unit (GA) and percent of the mean (GAM), assuming selection of superior $5 \%$ of the genotypes were estimated in accordance with the methods illustrated by Johnson et al., ${ }^{25}$ and categorized as low, moderate and high.

\section{Result and discussion}

\section{Analysis of variance and genotypes performance of okra}

Crop phenology and growth traits: The results of analysis of variances for 14 phenology and growth traits of 36 okra genotypes are presented in Table 1. Mean squares of phenology and growth traits of 36 okra genotypes were significant except non significant mean squares were observed for leaf length, leaf width and number of epicalyxes. These results indicated the presence of significant variations among genotypes for most phenology and growth traits that may give a good opportunity for breeders to identify best performing genotypes for traits of interest to improve in breeding programs. Muluken et al. ${ }^{15}$; Tesfa and Yosef ${ }^{11}$ are reported the presence of significant differences among genotypes for phenology and growth traits. Mihratu et al. ${ }^{9}$ also reported significant differences among 25 accessions for days to pod formation, days first flowering, days to $50 \%$ flowering, days to maturity, plant height, stem diameter, number of branch, fruit length, fruit diameter, fruit weight, fruit yield, number of mature pod, and fresh weight of mature pod.

The mean values of genotypes for crop phenology and growth traits showed variations for days to seedling emergence, days to first flowering, and days to $50 \%$ flowering ranged from 7.5 to $11,44.5$ to 71 and 48.5 to 77.5 , respectively. The genotypes showed variations for days to $90 \%$ maturity and number of harvest in the range between 75.5 and 104.5 days and 5.4 and 8, respectively. The seeds of 29621 and 29620 showed significantly delayed emergence compared to check varieties (SOH701, SOH714, and Bamia Humera) and to other genotypes. The accessions, 29617, 29418 had significantly delayed in days to first flowering and 50\% flowering as compared to check varieties and to other accessions. Accessions, 29052, 29416 and 
29617 were late for days to $90 \%$ maturity while 240204 and SOH714 were early maturing. The accessions, 29414, 29418, 2961829052 ,
29615 and 29616 had long duration of fruit harvest while 29411 and 29417 had short duration of fruit harvest.

Table I Mean squares from analysis of variance for 14 phenology and growth traits of 36 okra genotypes evaluated at Melkassa during $2018 / 19$

\begin{tabular}{|c|c|c|c|c|c|c|}
\hline \multirow{2}{*}{ Traits } & \multirow{2}{*}{$\operatorname{Rep}(I)$} & \multirow{2}{*}{$\begin{array}{l}\text { Blocks/ } \\
\text { Rep(Adj.) (I0) }\end{array}$} & \multirow{2}{*}{$\begin{array}{l}\text { Genotype } \\
\text { (Unadj.) (35) }\end{array}$} & \multicolumn{3}{|l|}{ Error } \\
\hline & & & & RCBD (35) & Intra block (25) & CV (\%) \\
\hline Days to $50 \%$ emergence & 0.22 & 0.42 & $2.41 * *$ & 0.39 & 0.38 & 7.04 \\
\hline Days to first flower & 9.39 & $|4.9|$ & $97.94 * *$ & 10.47 & 8.7 & 5.45 \\
\hline Days to $50 \%$ flower & 20.06 & 16.34 & $115.39 * *$ & 13.63 & 12.54 & 5.98 \\
\hline Days to $90 \%$ maturity & 25.68 & 2.11 & $137.04 * *$ & 3.82 & 4.51 & 2.43 \\
\hline Number of harvest & 0.61 & 0.6 & $\mathrm{I} .50 \mathrm{I} * *$ & 0.33 & 0.22 & 6.82 \\
\hline Stem diameter(mm) & 3.83 & $\mathrm{I} .47$ & $22.24 * *$ & 1.58 & 1.63 & 6.12 \\
\hline Plant height $(\mathrm{cm})$ & 43.71 & 53.86 & $2155.28 * *$ & 61.59 & 64.69 & 6.19 \\
\hline Number of primary branch & 0.09 & I.31 & $12.28 * *$ & 0.58 & 0.29 & 12.02 \\
\hline Number of internode & 2.72 & 2.96 & $73.27 * *$ & 2.69 & 2.59 & 6.21 \\
\hline Internode length $(\mathrm{cm})$ & 0.25 & 0.45 & $7.79 * *$ & 0.35 & 0.3 & 11.35 \\
\hline Leaf length(cm) & 1 & 9.71 & $9.24 \mathrm{~ns}$ & 6.95 & 5.84 & 13.86 \\
\hline Leaf width $(\mathrm{cm})$ & 0.13 & 17.06 & $17.15 \mathrm{~ns}$ & 13.87 & 12.59 & 15.29 \\
\hline Number of epicalyxes & 0.01 & I & I.06ns & 1.03 & 1.04 & $|0.3|$ \\
\hline Peduncle length (cm) & 0.05 & 0.04 & $0.4366 * *$ & 0.04 & 0.04 & 9.8 \\
\hline
\end{tabular}

ns, ${ }^{*}$ and $* *=$ nonsignificant, significant at $\mathrm{P}<0.05$ and $\mathrm{P}<0.0 \mathrm{I}$, respectively. Rep $=$ replication, Blocks/Rep (adj.) $=$ blocks in replication adjusted, Unadj. $=$ unadjusted, $\mathrm{RCBD}=$ randomized complete block design, and $\mathrm{CV}(\%)=$ coefficient of variation in percent. Number in parenthesis represents degree of freedom for the respective source of variation

The 33 accessions collected from Benishangul Gumuz Regional State had overall mean values greater than mean values of the three check varieties for all phenology and growth traits except internode length. A total of $28(84.85 \%)$ and $19(57.58 \%)$ of accessions collected from different Wored as of Benishangul Gumuz Regional State, western Ethiopia had mean performance greater than mean values of the three check varieties for days to seedling emergence and duration of fruit harvest, respectively. All except one accession collected from Benishangul Gumuz Regional State had delayed days to first flowering and days to 50\% flowering and all except two accessions had delayed maturity than the three check varieties (SOH701, SOH714, and Bamia Humera). Muluken et al. ${ }^{15}$ also reported delayed seed emergence, flowering and maturity of okra genotypes collected from Ethiopia than the two commercial varieties (SOH701) and (SOH714). Anteneh $^{26}$ and Fozia $^{27}$ also observed delayed seedling emergence, days to first flowering, days to $50 \%$ flowering and maturity of okra genotypes collected from Ethiopia than introduced SOH701 and SOH714 commercial varieties.

The variation among okra genotypes was in the range between 14.5 and $30.5 \mathrm{~cm}, 73.05$ and $194.5 \mathrm{~cm}$, and 1.3 to 12.7 for stem diameter, plant height and number of branches, whereas it was ranged from 13.5 to $39 \mathrm{~cm}$ and 2.5 to $10.25 \mathrm{~cm}$ for number of internodes, and internode length, respectively. The Genotypes (29615 and 29414), (29416 and T240204), (29418 and 29409) shows significant difference for plant branches, number of internode and internode length whereas genotypes (29408 and 29417), (29622 and 29417), and (T242444 and 29620) had significantly lower number of branches, number of internode and internode length as compared to checks and other Benishangul Gumuz collections, respectively.

Among the 33 accessions collected from Benishangul Gumuz Regional State, 93.94, 87.88 and $81.82 \%$ had mean values greater than mean values of check varieties for days to $90 \%$ maturity; stem diameter and plant height, respectively. Genotypes 39.39, 90.91 and $69.70 \%$ showed a mean values greater than mean values of check varieties for internode length, leaf length and number of epicalyxes, respectively. In addition, $96.97,84.85$ and $66.67 \%$ of genotypes had greater performance than the overall mean values of check varieties for leaf width, peduncle length as well as number of primary branches and number of internodes each, respectively. The results showed that most of collections from Benishangul Gumuz Regional state had more robust/vigorous growth characteristics than the commercial varieties. Muluken et al. ${ }^{15}$ also observed robust growth of okra genotypes collected from different regions of Ethiopia commercial varieties (SOH701) and (SOH714). He also reported that higher mean performances for growth traits (plant height, stem diameter, number of primary branches, number of internode and number of epicalyxes) than the two introduced commercial varieties. Anteneh ${ }^{26}$ reported the presence higher performance of Ethiopian okra collections than commercial varieties.

Researchers from different countries reported the presence of significant differences among okra genotypes for phenology and 
growth traits. Aminu et al. ${ }^{28}$ reported a mean value of $46.82,1.25 \mathrm{~m}$, 2.92 , for days to $50 \%$ flowering, plant height and number of primary branches, respectively. Chandra et al. ${ }^{29}$ also reported 47.33 to 54.67 , 1.47 to $3.53,102.53$ to $155.67 \mathrm{~cm}$, and 53.33 to 63.33 ranges for days to first flowering, number of primary branches, average plant height, and days to maturity, respectively. Shivaramegowda et al. ${ }^{30}$ was reported mean values of $41,2.08$, and $96.73 \mathrm{~cm}$ for days to first flowering, a number of primary branches and plant height respectively. Davinder et al..$^{31}$ also reported the presence of high genetic variability for agromorphological traits of $30 \mathrm{okra}$ accessions from India.
Fruit yield and yield components of okra genotypes: The results of analysis of variance (ANOVA) of 36 Okra genotypes for 11 fruit yield and yield components traits showed significant difference at $(\mathrm{P}<0.01)$ except for hundred seed weight and number of fruit ridges traits at $(\mathrm{P}<0.05)$ level of significance (Table 2). Similar results was reported by Muluken et al. ${ }^{15}$ and Mihretu et al. ${ }^{9}$ also reported the presence of significant difference among okra genotypes collected from Ethiopia for fruit length, fruit diameter, fruit weight, fruit ridge, fruit yield, number of mature pod, fresh weight of mature pod and dry weight of mature pod, number of seed per pod and hundred seed weight.

Table 2 Mean squares from analysis of variance for II tender fruit yield and yield components as well as 2 quality related traits of 36 okra genotypes evaluated at Melkassa during 2018/19

\begin{tabular}{|c|c|c|c|c|c|c|}
\hline \multirow{2}{*}{ Traits } & \multirow{2}{*}{$\operatorname{Rep}(1)$} & \multirow{2}{*}{$\begin{array}{l}\text { Blocks/ } \\
\text { Rep(Adj.) (I0) }\end{array}$} & \multirow{2}{*}{$\begin{array}{l}\text { Genotype } \\
\text { (Unadj.) (35) }\end{array}$} & \multicolumn{3}{|l|}{ Error } \\
\hline & & & & RCBD (35) & Intra Block (25) & CV (\%) \\
\hline Fruit length $(\mathrm{cm})$ & 0.01 & 0.76 & $37.27 * *$ & 0.84 & 0.87 & 7.87 \\
\hline Fruit diameter (mm) & 2.33 & 0.34 & $28.93 * *$ & 0.38 & 0.39 & 2.25 \\
\hline Average fruit weight (g) & 4.85 & 6.11 & $428.44 * *$ & 7.68 & 8.31 & 7.75 \\
\hline Number of fruits per plant & 89.76 & 36.49 & $187.39 * *$ & 29.63 & 26.88 & 23.87 \\
\hline Number of fruit ridge & 2.57 & 0.87 & $1.28 *$ & 0.61 & 0.5 & 10.86 \\
\hline Number of seed per pod (g) & 217.01 & 59.63 & $448.82 * *$ & 79.34 & 87.22 & 11.74 \\
\hline Hundred seed weight (g) & 0.55 & 0.19 & $0.44 *$ & 0.16 & 0.15 & 6.6 \\
\hline Seed yield per plant (g) & 7.17 & 1102.37 & $3002.77 * *$ & 580.19 & 371.31 & 19.33 \\
\hline Seed yield per hectare $(\mathrm{kg})$ & 5535.68 & 850596 & $2316952 * *$ & 447674 & 286506 & 19.33 \\
\hline Fruit yield per plant (g) & 13452 & 45120 & $|3986| * *$ & 18965 & 8503.08 & 13.08 \\
\hline Fruit yield per hectare (ton) & 10.38 & 34.81 & $107.92 * *$ & 14.63 & 6.56 & 13.08 \\
\hline Dry matter content of fruits (\%) & 2.65 & 1.24 & $\mid 4.5109 * *$ & 1.08 & 1.01 & 3.86 \\
\hline Mucilage content fruits (\%) & 0.02 & 1.12 & $41.525 * *$ & 1.64 & 1.84 & 9.96 \\
\hline
\end{tabular}

ns, $*$ and $* *=$ nonsignificant, significant at $\mathrm{P}<0.05$ and $\mathrm{P}<0.0 \mathrm{I}$, respectively. $\mathrm{Rep}=$ replication, Blocks $/$ Rep (adj.) $=$ blocks in replication adjusted, Unadj. $=$ unadjusted, $\mathrm{RCBD}=$ randomized complete block design, and $\mathrm{CV}(\%)=$ coefficient of variation in percent. Number in parenthesis represents degree of freedom for the respective source of variation

The mean values of tested genotypes are exhibited variation in ranges $5.5 \mathrm{~cm}$ to $22.3 \mathrm{~cm}, 21.6 \mathrm{~mm}$ to $35.75 \mathrm{~mm}, 17.04 \mathrm{~g}$ to $67.23 \mathrm{~g}, 9.7$ to 55.2 , and 5 to 8.3 with the mean values of $11.83 \mathrm{~cm}, 27.79 \mathrm{~mm}$, $37.19(\mathrm{~g}), 21.72$, and 5.54 for fruit length, fruit diameter, average fruit weight, number of tender fruit per plant and number of fruit ridge, respectively. On another hand, the mean values of 704.82g, 19.58ton/ $\mathrm{ha}^{-1}$, for fruit yield per plant, fruit yield per hectare, with a ranged from 339.71 to $1183.6 \mathrm{~g}$ and 9.44 to 32.88 tons, respectively. The genotypes had wide range of variation 58.5 to $111.9,5.08$ to $7.16 \mathrm{~g}$, 33.48 to $198.04 \mathrm{~g}$, and 929.95 to $5501.01 \mathrm{~kg} / \mathrm{ha}^{-1}$ and with mean values $79.56,5.93 \mathrm{~g}, 99.7 \mathrm{~g}$, and $2769.34 \mathrm{~kg} / \mathrm{ha}^{-1}$ for number of seed per plant, hundred seeds weight, seed yield per plant and seed yield per hectare, respectively. The Genotypes 29408, T240204, 29417, 29618 and 29409 showed significantly higher for fruit length, fruit diameter, average fruit weight, number of tender fruit per plant and number of fruit ridge whereas genotypes 29624, 29625, 29618, 29411 and 29619 shows significantly lower as compared to three check varieties and other Benishangul Gumuz collections, respectively. In addition genotypes 29618 and 29620 showed significantly higher and lower in fruit yield performance, respectively. Genotypes 29409, 242449A, and 29618 shows the highest performance for number of seed per pod, weight of hundred seed and seed yield per hectare- ${ }^{1}$ whereas genotypes 29052, 29412 and 29417 had the lowest performance as compared to checks and to the rest of genotypes collected from regional states, respectively. Muluken et al. ${ }^{15}$; Mihretu et al. ${ }^{9,10}$ and Tesfa and Yosef ${ }^{11}$ reported a greater degree of variability in all Ethiopian okra collection and higher in performance for fruit and fruit yield components than introduced commercial varieties.

Similar results are reported from other countries, Chandra et al..$^{29}$ reported that five accession are evaluated at India and shows variation for a number of fruits per plant that ranged from 9.17 to 20.22, fruit length from 7.03 to $15.08 \mathrm{~cm}$ and fruit width from 1.29 to $1.69 \mathrm{~cm}$. Average fruit weight varied from 7.79 to $14.69 \mathrm{~g}$, a number of fruit ridge $4.67-7$, fruit yield per plant 108.4 to 291.97 and fruit yield per hectare 7.23 to 19.46 tha $^{-1}$. Aminu et al..$^{28}$ have also reported the mean values of $13.08 \mathrm{~cm}, 1.54 \mathrm{~cm}, 15.25(\mathrm{~g})$ and $523.75(\mathrm{~g})$ for, number of pod per plant, fruit length, fruit diameter, fresh pod weight and pod yield per plant, respectively. Oppong-Sekyere et al. ${ }^{32}$ reported relatively wide ranges of variations for all morphological characters observed. A number of fruits per plant, fruit weight, and total fruit production often show high variability as compared to other quantitative traits. ${ }^{33}$ 
Among the 33 accessions collected from Benishangul Gumuz Regional State 15 (45.45\%), 18 (54.55\%), 18 (54.55), 21 (63.64\%), and 18 (54.55) of genotypes had a mean greater than the mean values of checks varieties for fruit length, fruit diameter, average fruit weight, number of tender fruit per plant, and number of ridges, respectively. The mean performance of $25(75.76 \%)$ and $21(63.64 \%)$ okra genotypes showed higher than the mean performance of three checks for fruit and seed yields, respectively. Sixteen (48.48\%) and $12(36.36 \%)$, of genotypes showed higher mean values than the mean values of three commercial varieties for number of seed per pod and weight of hundred seed, respectively. The result indicated that the genotypes collected from Benishangul Gumuz region had higher mean values than the mean values of checks varieties viz. Bamia Humera, $\mathrm{SOH} 701$ and SOH714 for all tender fruit yield and yield components except for fruit length and weight of hundred seed.

They showed double values for pod and seed yield as compared to checks. This showed that the higher degree of variability and chance of developing varieties for tender fruit yield and yield components through collection and selection of okra genotypes with the desired traits.

\section{Fruit quality related traits of okra genotypes}

The genotypes showed highly significant $(\mathrm{P}<0.01)$ differences for percentage dry matter contents of tender fruits and fruits percentage of mucilage content (Table 2). The tender fruits of genotypes had dry matter content in the range between 22.035 and $34.55 \%$ with overall mean values of $26.08 \%$, whereas mucilage content of fruits was in the range between 6.93 and $23.01 \%$ with overall mean values of $13.63 \%$ Anteneh $^{26}$ observed the ranges from 26.45 to $54.03 \%$ and 4 to $25.33 \%$ for dry matter content and mucilage contents of fruits, respectively. Gemede et al., ${ }^{34}$ reported the mean mucilage content of Ethiopian okra is higher than the value of Nigerian okra.

Genotypes having lowest and highest dry matter and mucilage contents are 29617, 29624 and 29408, 29619 respectively. Genotypes 29624 and 29619 are significantly different in contrast to checks by having the highest dry matter and mucilage contents respectively which is $23(69.7 \%)$ and $24(72.73 \%)$ percentage of dry matter contents and percentage of mucilage contents compared to the mean value of three checks, respectively. This result indicates the possibility of improving the mucilage and dry matter contents of okra from Benishangul Gumuz collections as it's the major determinants of okra nutritional qualities

\section{Estimation of variability components}

Genotypic and phenotypic variations: The estimated genotypic (GCV) and phenotypic (PCV) coefficient of variations for 24 quantitative traits of okra genotypes are presented in (Table 3). The genotypic and phenotypic coefficients of variation ranged from 6.3 to $54.19 \%$ and 9.19 to $55.51 \%$, respectively. Among evaluated traits, days to $90 \%$ maturity and weight of hundred seed showed lower both for PCV and GCV, while number of fruit ridge and percentage of dry matter content had less than $10 \%$ GCV. Number of the branch, followed by a number of tender fruit per plant, internode length, seed yield, average fruit weight, pod yield, fruit length, percentage of mucilage content, plant height, internode length, and peduncle length had higher GCV and PCV.
According to Sivasubramanian and Madhavamenon (1973) PCV and GCV can be categorized as low $(<10 \%)$, moderate $(10-20 \%)$ and high $(>20 \%)$. Based on this delineation PCV and GCV for days to $50 \%$ emergence, days to first flowering, days to $50 \%$ flowering, stem diameter, fruit diameter, and number (frequency) of fruit harvest had moderate values (10-20\%). The difference between the values of PCV and GCV was low $(<5 \%)$ for all of the traits except $6.41 \%$ for number of tender fruit per plant. This result is consistent with the finding of Adeoluwa and Kehinde ${ }^{35}$ who reported low PCV and GCV for 100 seed weight and number of ridges per fruit and Ehab et al. ${ }^{36}$ and Aminu et al. ${ }^{28}$ reported that number of pods per plant, fruit length, plant height, the number of primary branches, fresh pod length, fresh pod yield per plant and fresh seed per pod exhibited high values of more than $20 \%$ for both PCV and GCV with a considerably low degree of variation between them. Sibsankar et al ${ }^{37}$ also estimated low PCV and GCV values for days to first flowering and numbers of ridge per fruit. In contrast, Muluken et al. ${ }^{15}$ reported the highest GCV and PCV are observed for number of matured pod per plant and number of primary branches 34.14 and 27.19 , respectively.

The large magnitude of PCV and GCV with a small difference between the two heredity parameters indicated a smaller amount of environmental influence on the phenotypic expression; several researchers reported the consistent differences of okra cultivars due to cultivars and environmental interactions..$^{36,38,39}$ Therefore, high phenotypic and genotypic coefficients of variation is an indication of the less influence of environmental factors in the expression of traits and the higher chance to improve the traits through selection breeding.

Heritability and genetic advance: Estimates of heritability in a broad sense $\left(\mathrm{H}^{2}\right)$ and genetic advance as percent of the mean (GAM) for 24 quantitative traits of okra genotypes are presented in (Table 3). The heritability values ranged from $43.46 \%$ to $97.34 \%$ for a number of fruit ridge to fruit diameter respectively. As suggested by Johnson et al. (1955), heritability values are categorized as low $(<30 \%)$, moderate $(30-60 \%)$ and high $(>60 \%)$. Based on this classification, all traits had high heritability except a number of ridge and hundred seed weight which had moderate heritability. The high values of the heritability indicate that in the future programs of okra improvement for the characters such as diameter of the fruit, length of the fruit and number of seeds per pod. It is important to apply some backcross to concentrate these characters in genotypes because a lot of traits appear to be controlled by the genes with additive effects. The heritability is a good index of the degree of transmission of the characters from parents to their offspring. ${ }^{40}$ The consistency in the performance of progeny in succeeding generations depends mainly on the magnitude of the heritable portion of the variation. Heritability indicates the possibility and extent to which improvement can be brought about through selection and it may be of broad and narrow senses. ${ }^{24}$

The genotypes showed genetic advance as percent of mean in the range between 9.16 and $109.14 \%$ for the trait of hundred seed weight to a number of branches, respectively. According to Johnson et al., ${ }^{25}$ the range of genetic advance as percent mean are classified as low $(<10 \%)$, moderate $(10-20 \%)$ and high $(>20 \%)$. Accordingly, all the traits had high GAM at 5\% selection intensity except moderate for days to $90 \%$ maturity, number of fruit ridge and percentage of dry matter content whereas low for hundred seed weight. Similar results reported by Muluken et al. ${ }^{15}$ in which genetic advance was observed for number of branches, fresh weight of mature pod, number of 
mature pod per plant, fruit length, fruit weight, plant height, fruit yield $\mathrm{ha}^{-1}$,dry weight of mature pod, number of fruit per plant, days to $50 \%$ flowering, days tomaturity and number of seeds per pod but disagree for high heritability in number of ridge per pod. High genetic advance (198.15) was reported for the number of primary branches. ${ }^{16}$

Table 3 Estimates of range, mean and variability components of 36 okra genotypes evaluated at Melkassa in 2018/I9

\begin{tabular}{|c|c|c|c|c|c|c|c|c|c|c|}
\hline Variables & Range & Mean & SE & $\sigma^{2} \mathbf{g}$ & $\sigma^{2} \mathbf{p}$ & GCV & PCV & H2 (\%) & GA & GAM $\%$ \\
\hline Eme & $7-11$ & 8.78 & 0.5 & 1.02 & 1.4 & 11.48 & 13.46 & 72.65 & I.77 & 20.18 \\
\hline Dflo & $44-71$ & 54.17 & 2.21 & 44.62 & 53.32 & 12.33 & 13.48 & 83.68 & $|2.6|$ & 23.27 \\
\hline Flo & $47.5-77.5$ & 59.25 & 2.59 & 51.42 & 63.97 & 12.1 & 13.5 & 80.39 & 13.26 & 22.39 \\
\hline Mat & $74.5-104.5$ & 87.51 & 1.38 & 66.27 & 70.77 & 9.3 & 9.61 & 93.63 & 16.25 & 18.57 \\
\hline $\mathrm{PH}$ & $73.05-194.5$ & 129.88 & 5.55 & 1045.3 & 1109.98 & 24.89 & 25.65 & 94.17 & 64.73 & 49.84 \\
\hline PB & $1.3-12.7$ & 4.52 & 0.42 & 5.99 & 6.29 & 54.19 & 55.51 & 95.31 & 4.93 & 109.14 \\
\hline $\mathrm{NI}$ & $13.5-39$ & 25.92 & 1.16 & 35.34 & 37.93 & 22.94 & 23.76 & 93.17 & II.84 & 45.68 \\
\hline IL & $2.5-10.25$ & 4.86 & 0.41 & 3.74 & 4.05 & 39.82 & $4 I .4 I$ & 92.48 & 3.84 & 79 \\
\hline $\mathrm{FL}$ & $5.5-22.3$ & 11.83 & 0.65 & 18.2 & 19.07 & 36.07 & 36.92 & 95.45 & 8.6 & 72.7 \\
\hline FD & $21.6-35.75$ & 27.79 & 0.43 & 14.27 & 14.66 & 13.59 & 13.78 & 97.34 & 7.69 & 27.66 \\
\hline AFW & $17.04-67.23$ & 37.19 & 1.96 & 210.06 & 218.38 & 38.97 & 39.73 & 96.19 & 29.33 & 78.85 \\
\hline NTFPP & $9.7-55.2$ & 21.72 & 3.8 & 80.25 & 107.14 & 41.24 & 47.65 & 74.91 & 16 & 73.64 \\
\hline NR & $5-8.3$ & 6.54 & 0.53 & 0.39 & 0.89 & 9.52 & 14.44 & 43.46 & 0.85 & 12.95 \\
\hline YPP & $339.71-1183.60$ & 704.82 & 72.37 & 65678.96 & 74182.04 & 36.36 & 38.64 & 88.54 & 497.48 & 70.58 \\
\hline yhaton & $9.44-32.88$ & 19.58 & 2.01 & 50.68 & 57.24 & 36.36 & 38.64 & 88.54 & 13.82 & 70.58 \\
\hline NSPP & $58.5-111.9$ & 79.56 & 6.3 & 180.8 & 268.02 & 16.9 & 20.58 & 67.46 & 22.78 & 28.64 \\
\hline SDW & $5.08-7.16$ & 5.94 & 0.3 & 0.14 & 0.3 & 6.39 & 9.19 & 48.33 & 0.54 & 9.16 \\
\hline syppg & $33.48-198.04$ & 99.7 & 14.86 & 1315.73 & 1687.04 & 36.38 & 41.2 & 77.99 & 66.09 & 66.29 \\
\hline Nha & $5.4-8$ & 6.93 & 0.31 & 0.64 & 0.86 & 11.54 & $|3.4|$ & 74.14 & 1.42 & 20.51 \\
\hline DMC (\%) & $22.035-34.55$ & 26.08 & 0.73 & 6.75 & 7.76 & 9.96 & 10.68 & 86.93 & 5 & 19.16 \\
\hline PMC (\%) & $6.93-23.01$ & 13.63 & 0.9 & 19.84 & 21.68 & 32.69 & 34.17 & 91.49 & 8.79 & 64.5 \\
\hline
\end{tabular}

Eme $=$ Days to $50 \%$ emergence, $\mathrm{Dflo}=$ Days to first flower, $\mathrm{Flo}=$ Days to $50 \%$ flowering, Mat $=$ Days to $90 \%$ maturity, $\mathrm{SD}=\mathrm{Stem}$ diameter (mm), $\mathrm{PH}=\mathrm{Plant}$ height $(\mathrm{cm}), \mathrm{PB}=\mathrm{Number}$ of primary branch, $\mathrm{NI}=$ Number of internode, IL= Internode length $(\mathrm{cm}), \mathrm{PL}=$ Peduncle length $(\mathrm{cm}), \mathrm{FL}=\mathrm{Fruit}$ length $(\mathrm{cm}), \mathrm{FD}=\mathrm{Fruit}$ diameter $(\mathrm{mm}), \mathrm{AFW}=$ Average fruit weight $(\mathrm{g}), \mathrm{NTFPP}=$ Number of tender fruit per plant, $\mathrm{NR}=$ Number of fruit ridge,YPP= Pod yield per plant $(\mathrm{g}), \mathrm{Yhaton}=\mathrm{Pod}$ yield per hectare (tons), NSPP= Number of seed per pod, SDW= Hundred seed weight, SYPP= Seed yield per pod $(\mathrm{g})$, Syph= Seed yield per hectare $(\mathrm{Kg})$, Nha= Number of harvest, $\mathrm{DMC}=$ Dry matter content $(\%), \mathrm{PMC}=$ Mucilage content $(\%)$

High heritability coupled with high genetic advance as percent of the mean was more valuable in predicting the effect of selection because heritability is a single numerical expression on the ratio of the two variances which may not lead to success if the selection is based on heritability estimates alone. ${ }^{25}$ In this regard high heritability coupled with high genetic advance for all traits except moderate genetic advance for days to $90 \%$ maturity and percentage of dry matter content but, moderate heritability for a number of ridge and hundred seed weight coupled with moderate to low in genetic advances respectively. Therefore, this will pave ways for the success of selection of genotypes for the improvement program since, heritability estimates provide a background genetic information on the inheritance of traits from parents to progenies as well as the amount of genetic progress that can be made in selection of a trait of interest and genetic advance under selection is helpful in detecting the actual genetic gain expected. ${ }^{41,42}$

\section{Conclusion and recommendation}

This research identified the presence of significant difference among genotypes at $(\mathrm{P}<0.01)$ and $(\mathrm{P}<0.05)$ level of significance for all quantitative traits except leaf length, leaf width and number of epicalyxes. Among local collection many genotypes had better performance in terms of pod and seed yield as compared to checks Viz. Bamia Humera, SOH701 and SOH714. This indicated that the 
genotypes collected from regional state had high variability both in terms of fresh pod yield as well as seed yield. Therefore, the result of this study is an indicator for the presence of higher chance to develop okra varieties for both pod and seed yield through selection/crossing of okra genotype collected from Benishangul Gumuz regional state.

The result of variability components indicates that number of primary branches, followed by a number of tender fruit per plant, internode length, seed yield, average fruit weight, pod yield, fruit length, percentage of mucilage content, plant height, internode length, and peduncle length had higher GCV and PCV; while days to $90 \%$ maturity and hundred seed weight had the low GCV and PCV. In addition these traits had shown high heritability and genetic advance as percent of mean except moderate for number of ridge in both and hundred seed weight and percentage of dry matter content, respectively. But low GAM for hundred seed weight. The result observed in this study was the presence of a wide genetic variation among genotypes collected from Benishangul Gumuz Regional State and traits were highly heritable and variation observed was due to genetic contributions. Therefore, it is recommended to conduct similar experiment over seasons and locations since this research was conducted for one season and at one location and followed by molecular characterization

\section{Acknowledgments}

Before all a would like to thank almighty God (Allah) for giving me strength and substance to complete this work and my appreciation goes to all guys involved in this work from idia inception to the end of writing. Finally we are truely thanks Ethiopian Biodiversity institute for the whole financial support, Haramaya University as well as Melkasa agricultural research center for their provisions.

\section{Financial support}

The research was fully sponsored by Ethiopian biodiversity institute.

\section{Funding}

None.

\section{Conflicts of interest}

The authors declare there are no conflicts of interest.

\section{References}

1. Kisher DS, Arya K, Yogeesh KJ, et al. Genotypic variation among okra (Abelmoschus esculentus (L.) Moench) germplasms in South India Plant Breeding and Biotechnology. 2016;4(2):234-241.

2. Santos BM, Dittmar PJ, Olson SM, et al. Okra production in Florida University of Florida IFAS extension; 2012:163-171.

3. Muhammad RS, Muhammad A, Khurram Z, et al. 2013.Growth, yield and seed production of okra as influenced by different growth regulators. Pakistan Journal of Agricultural Science. 2013;50(3):387392.

4. Osawaru ME, Ogwu C., Omologbe J. Characterization of three Okra [Ablemoschusesculentus (L.)] accessions using morphology and SDSPAGE for the basis of conservation. Egyptian Academic Journal of Biological Sciences H. Botany. 2014;5(1):55-65.

5. Lamont WJ. Okra-A versatile vegetable crop. Horticultural Technology. 1999;9:179-184.
6. Saifullah M, Rabbani MG. Evaluation and characterization of Okra (Abelmoschus esculentus L. Moench.) cultivars. SAARC Journal of Agriculture. 2009;7(1):92-99.

7. Haruna S, Aliyu BS, Bala A. Plant gum exudates (Karau) and mucilages, their biological sources, properties, uses and potential applications: A review. Bayero Journal of Pure and Applied Sciences. 2016;9(2):159-165.

8. Moekchantuk T, Kumar P. Export okra production in Thailand. Intercountry programme for vegetable IPM in South and SE Asia phase II Food and Agriculture Organization of the United Nations, Bangkok, Thailand, 56. 2004.

9. Mihretu Y, Weyessa G, Adugna D. Multivariate Analysis among okra [Abelmoschus esculentus (L.)Moench] collection in South Western Ethiopia. Journal of Biological science. 2014;9(2):43-50.

10. Mihretu Y, Weyessa G, Adugna D. Variability and association of quantitative characters among okra [Abelmoschus esculentus (L.) Moench] collection in South Western Ethiopia. Journal of Biological science. 2014;14:336-342.

11. Tesfa B, YosefA. Characterization of Okra (Abelmoschus esculentus (L.) Moench) Germplasms Collected from Western Ethiopia. International Journal of Research in Agriculture and Forestry. 2016;3(2):11-17.

12. MoANR (Ministry of Agriculture and Natural Resources). Crop variety registers Issue No. 19, p.211. Ethiopia: Addis Abeba; 2016.

13. Tesfaye Awas. Plant diversity in western Ethiopia: ecology, ethnobotany, and conservation, dissertation presented for the degree of doctoral philosophy, department of biology, faculty of mathematics and natural sciences. Norway: University of Oslo; 2007.

14. Akash MW, Shiyab SM, Saleh MI. Yield and AFLP analyses of interlandrace variability in okra (Abelmoschus esculentus L.). Life Science Journal. 2013;10(2):2771-2779.

15. Muluken D, Wassu M, Endale G. Genetic diversity of ethiopian okra collections through multivariate analysis at werer, rift valley of Ethiopia. The International Journal Of Science and Technolodge. 2015;3(8):186-193.

16. Muluken D, Wassu M, Endale G. Variability, heritability and genetic advance in Ethiopian Okra [Abelmoschus esculentus (L.) Monech] Collections for tender fruit yield and other agro-morphological traits. Journal of Applied Life Sciences International. 2016;4(1):1-12.

17. Wassu M, Anteneh B, Kumar V. Characterization and Evaluation of Okra [Abelmoschus esculentus (L.) Moench] Collections in Eastern Ethiopia. Proceedings of 34th Annual review workshop, 6-8 April 2017. Ethiopia: Haramaya University; 2017:211-238.

18. Melkassa. Agricultural research center. Home page datas; 2019.

19. IPGRI. Okra Descriptor list. International Crop Network Series 5. International Board for Plant Genetic Resources (IBPGR), Rome, Italy; 1991.

20. SAS Institute. SAS software. Cary. NC. USA: SAS Institute INC; 2004.

21. Burton GW, De Vane EH. Estimating heritability in tall fescue (Fistveaarundiancea) from the replicated clonal material. Agriculture Journal. 1953;45:284-291.

22. Sivasubramaniah S, Meron M. Heterosis and inbreeding depression in rice. Madras Agriculture Journal. 1973;60:1139-1144.

23. Falconer DS, Mackay TFC. An Introduction to quantitative genetics Printice Hall London; 1996. 464 p.

24. Robinson HF. Quantitative genetics in relation to breeding on the centennial of Mendelism. Indian Journal of Genetics. 1966;26:171187. 
25. Johnson HW, Robinson HF, Comstock RE. Estimation of the genetic and environmental variability of soybean. Agronomy Journal. $1955 ; 47: 314-318$

26. Anteneh Bekele. Characterization and evaluation of indigenous and exotic okra [Abelmoschus esculentus (L.) Moench] genotypes for yield and yield related traits at Dire Dawa, Eastern Ethiopia. MSc Thesis. Ethiopia: Haramaya University; 2017.

27. Fozia Yimam. Genetic diversity and association of seed yield and related traits of Okra [Abelmoschus esculentus (L.) Moench] in Ethiopia. MSc thesis. Haramaya, Ethiopia: Haramaya University; 2018.

28. Aminu D, Bello OB, Gambo BA, et al. Varietal performance and correlation of okra pod yield and yield components. Acta Universitatis Sapientiae, Agriculture, and Environment. 2016;8(1):112-125.

29. Chandra S, Bhardwaj ML, Kumar R, et al. Estimation of parameters of variability for different quantitative traits in okra, [Abelmoschus esculentus (L) Moench]. International Journal of Farm Sciences. 2014;4(3):33-41.

30. Shivaramegowda KD, Krishnan A, Jayaramu YK, et al. Genotypic variation among okra (Abelmoschus esculentus (L.) Moench) germplasms in South India. Plant Breeding and Biotechnology. 2016;4(2):234-241.

31. Davinder Singh, Dudi BS, Dhankhar SK, et al. Genetic diversity analysis of okra genotypes using morphological markers. International Journal of Current Microbiology and Applied Sciences. 2018;7(1):2319-7706.

32. Oppong-Sekyere D, Akromah R, Nyamah EY, et al. Characterization of okra (Abelmoschus spp. L.) germplasm based on morphological characters in Ghana. Journal of Plant Breeding and Crop Science. 2011;3(13):367-378.

33. Ahiakpa JK, Kaledzi PD, Adi EB, et al. Genetic diversity, correlation and path analyses of okra [Abelmoschus spp. (L.) Moench] germplasm collected in Ghana. International Journal of Development and Sustainability. 2013;2(2):1396-1415.

34. Gemede HF, Haki GD, Beyene F, et al. Indigenous Ethiopian okra (Abelmoschus esculentus) mucilage: A novel ingredient with functional and antioxidant properties. Food Sci Nutr. 2018;200:1-9.
35. Adeoluwa OO, Kehinde OB. Genetic variability studies in West African okra (Abelmoschus caillei). Agriculture and Biology Journal of North America. 2013;2(10):1326-1335.

36. Ehab AAI, Mohamed YA, Ali MM. Genetic behavior of families selected from some local okra [Abelmoschus esculentus (L.) Moench] populations in Egypt. Plant Breeding Biotechnology. 2013;1(4):396405 .

37. Sibsankar D, Arup C, Sankhendu BC, et al. Genetic parameters and path analysis of yield and its components in okra at different sowing dates in the Gangetic plains of eastern India. African Journal of Biotechnology. 2012;11(95):16132-16141.

38. AdeOluwa OO, Kehinde OB. Genetic variability studies in West African Okra (Abelmoschus caillei). Agriculture and Biological Journal of North America. 2011;2(10):1326-1335.

39. Adekoya MA, Ariyo OJ, Kehinde OB, et al. Correlation and path analyses of seed yield in okra (Abelmoschus esculentus (L.) Moench) grown under different cropping seasons. Pertanika Journal of Tropical Agricultural and Science. 2014;37(1):39-49.

40. Phani Krishna M, Hameedunnisa Begum A, Manohar Rao, et al Estimation of heritability and genetic advance in Okra [Abelmoschus esculentus (L.) Moench.]. Plant Archives. 2015;15(1):489-491.

41. Ahiakpa JK, Amoatey HM, Amenorpe G, et al. Mucilage Content of 21 accessions of Okra (Abelmoschus spp L.). Scientia Agriculture. 2014;2(2):96-101.

42. Tripathi KK, Govila OP, Ranjini W, et al. Biology of okra [Abelmoschus esculentus (L).Moench]. serious of crop specific biology document. Ministry of Environment and forests government of India and department of biotechnology ministry of science and technology government of India; 2011. 